\title{
Türkiye'de Eğitim Gören Yabancı Öğrencilerin Türkçeye İlişkin Görüşleri: Sakarya Üniversitesi Örneği
}

\author{
Rabia GÜRBÜZ* İsmail GÜLEÇ**
}

Öz

Yabancılara Türkçe öğretimi son dönemde eğitim alanında öne çıkan, popülerliği ar-tan alanlardan biri haline gelmiştir. Günümüz dünyasında Türkiye' nin dünya görü-şü, diğer devletlerle olan ilişkileri, gerek ekonomik gerekse sosyal anlamdaki ilerleme-leri özellikle yabancı öğrencilerin eğitim alanında tercih seçenekleri arasına girmiştir. Bu gelişmeler ışığında görülmüştür ki hem lisans hem de lisansüstü eğitimleri için Türkiye'yi tercih eden yabancı ögrrencilerin sayısında son yıllarda gözle görülür bir artış yaşanmıştır. Bu şekilde artan ilginin öğrenci sayısını artırmasıyla birlikte yabancılara Türkçe öğretimi üzerine yapılan çalışmalarda da bir artış başlamıştır. Yabancı öğrencilerin eğitim almak için Türkiye'yi seçme nedenleri araştırmacıların dikkatini çekmektedir. Öğrencilerin eğitimlerinin yanı sıra Türkiye ve Türkçeye karşı görüşleri de bu kapsamda önem arz etmektedir. Bu çalışmanın amacı Türkiye'de lisans ve lisansüstü eğitim gören yabancı öğrencile-rin Türkçeye ilişkin görüşlerini belirlemektir. Araştırma, nitel bir çalışmanın ürünü olup veri toplama aracı olarak araştırmacılar tarafından geliştirilmiş yarı yapılandı-rılmış görüşme formu soruları kullanılmıştır. Görüşme formunda yer alan sorular ya-bancı öğrencilerin Türkçeye ilişkin görüşlerini ölçmeye yönelik hazırlanmıştır. Bu sorular, uzman görüşü alındıktan sonra tekrar düzenlenmiş ve son hâli verilmiştir. Çalışmanın örneklemini Sakarya Üniversitesinde eğitim alan lisans ve lisansüstü programlara kayıtlı yabancı öğrenciler oluşturmaktadır.

Anahtar Kelimeler: Yabancılara Türkçe öğretimi, lisans ve lisansüstü eğitimi, Türkçe öğretimi.

\section{Ideas On Turkish Of Foreign Students Who Are Educating In Turkey: Example of Sakarya University}

\begin{abstract}
Teaching Turkish to the foreigners has become one of the featured fields of education. In today's world, Turkey's world view, its relations with other countries, its progress in ei-ther economic or social fields have led teaching Turkish to become one of the educational choices of foreign students. With the help of these improvements it is seen that the amount of the undergraduate and graduate students who prefer Turkey has increased remarkable. Even the studies made on Turkish has increased thanks to increasing num-ber of students. Reasons of foreign students choosing Turkey in order to take education have drawn researchers' attention. Besides students' education, their
\end{abstract}

\footnotetext{
*Arş. Gör., Sakarya Üniversitesi, rabiagurbuz@sakarya.edu.tr

** Prof. Dr., Kıbrıs Sosyal Bilimler Üniversitesi, ismail.gulec@kisbu.edu.tr
} 
thoughts about Turkey and Turkish is also important within this framework. Purpose of these studies is to undergraduate and graduate students' thoughts about Turkish. Research is a production of a qualitative study. In this research, semi structured interview form questions prepared by researchers were used to gather information. Questions on the interview form were prepared to measure the foreign students' thoughts about Turkish. These questions were readjusted after taking experts' ideas and the finalized. Sample of the research is foreign students who are registered to the under-graduate and graduate programs of Sakarya University.

Keywords: Teaching Turkish to the foreigners, education of undergraduates and graduates, teaching Turkish.

\section{GíRIŞ}

Son yıllarda teknolojinin gelişimi ile bilgiye ulaşım kolaylaşmış ve böylece insanlar uluslararası etkileşime girmeye başlamışlardır. Dünyadaki bu hızlı değişim ve etkileşim sonucunda insanlar arasındaki iletişim artmıştır. Türkiye'nin son yillarda sosyal ve ekonomik alanlarda olduğu kadar devletlerarası ilişkiler ve eğitim alanında gösterdiği gelişimin dikkat çekici olması ve aynı zamanda Türkiye'nin burs ve eğitim imkânlarının da cazipliği, yabancıların Türkiye'ye olan ilgisini arttırmıştır. Erasmus gibi öğrenci ve öğretim elemanı değişim programları da Türk eğitimi için farklı bir hareketlilik kaynağı olmuştur (Yağmur, 2013).
2010-2011 eğitim-öğretim yılında Türkiye'de eğitim veren üniversitelere yeni kayıt yaptıran yabancı öğrenci sayısı 7.039, toplam yabancı öğrenci sayısı ise 25.545 olarak saptanmıştır. (WEB1) 2011-2012 eğitim-öğretim yılında ise yeni kayıtlı yabancı öğrenci sayısı 8.410, toplam öğrenci sayısı 31.170 olmuştur (WEB2). 20122013 eğitim-öğretim yılına gelindiğinde yeni kayıt yaptıran öğrenci sayısı 12.903, toplam yabancı öğrenci sayısı 43.251 olarak hesaplanmıştır (WEB3). Geçtiğimiz üç eğitim-öğretim yılına bakıldığında bir önceki döneme göre öğrenci sayılarının artış gösterdiğini söylemek mümkündür. Bu sayılar, yabancı öğrencilerin eğitim için her geçen yıl Türkiye'yi eğitim ve öğretim için daha çok tercih ettiğini göstermektedir.

60000

45000

30000

15000

0

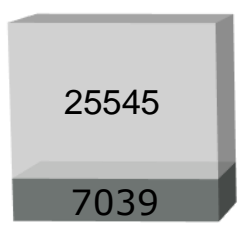

2010-2011

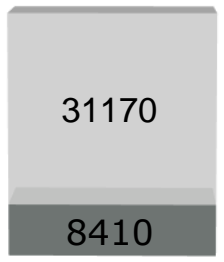

$2011-2012$

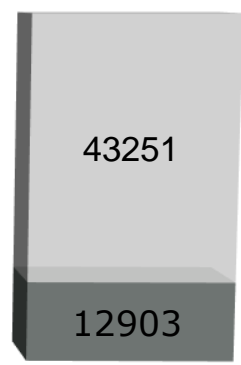

2012-2013

Şekil 1. Yıllara göre yabancı öğrencilerin üniversiteye kayıt sayıları (WEB1; WEB2; WEB3)

Türkçenin yabancı dil olarak öğretimi son yıllarda önem kazanmıştır. Türk dünyası öğrenci projesi kapsamında 1991 yılından itibaren gençler lise ve üniversitelerde okumak, yüksek lisans ve doktora yapmak amacıyla Milli Eğitim Bakanlığ tedir (Açık, 2008:2). Ülkemizde bu alanda üniversitelerimizin Türkçe Eğitimi bölümlerinde 
çalışmalar yürütülmektedir (Alyılmaz, 2010). Ayrıca üniversiteler bünyesinde Türkçenin yabancı dil olarak öğretimi ile ilgili yüksek lisans ve doktora programları açılmakta ve bu programlarda alana katkı sağlayacak çalışmalar yapılmaktadır (Göçer ve Moğul, 2011). Yunus Emre Enstitüsü, yabancllara Türkçe öğretimi açısından önemli kurumlardandır. Yunus Emre Enstitüsü'nün çeşitli üniversitelerle imzalamış olduğu "Türkoloji Projesi İşbirliği Protokolü" ile yurt dışında da Türk Dili ve Edebiyatı eğitimi almak isteyen yabancı öğrencilere ulaşılmıştır. Ayrıca üniversitelerin bünyelerinde kurulan çeşitli dil eğitim merkezleri de bulunmaktadır. Ülkemize üniversite eğitimi almaya gelen yabancıların ilk karşılaştıkları kurumlar, bu öğrencilere gerek duydukları Türkçe eğitimini vermek için kurulan TÖMER'lerdir. (Güleç ve İnce, 2013, s:98)

Türkçe öğretimi faaliyetlerinin artması ve ülkemize gelen yabancı öğrencilerin çoğalması beraberinde yabancı öğrencilerin yaşadı $\breve{1}$ sorunları ve doğan ihtiyaçlarını da getirmiştir. Türkiye'de yaşamaya başlayan yabancı öğrenciler sosyal ve kültürel yönden Türkiye'deki yaşama ayak uydurmaya çalışmakta aynı zamanda Türk vatandaşlarıyla anlaşabilmek ve derdini anlatabilmek adına iletişim de kurmaya başlamaktadır. Bu durum öğrencilerin zaman zaman zorlanmasına, uyum sağlamada sıkıntı çekmesine dolayısıyla da çeşitli sorunlar yaşamasına neden olmaktadır.

Alan yazında yabancı öğrencilerin yaşadığı kültürel uyum zorluğu ve sorunlara yönelik çalışmalar mevcuttur. Özellikle yabancılara Türkçe öğretilirken karşılaşılan sorunlar üzerine yapılmış çalışmalar bu konuda öğretim programlarının, eğitim verenlerin ve materyallerin eksikliklerini belirlemeye yöneliktir. (Doğan 1989; Açık 2008; Karababa 2009; Durmuş 2013). Biçer, Çoban ve Bakır'ın (2014) yapmış oldukları çalışmada, temel dil becerisine ilişkin sorunların belirlenmiş ve çözüm önerileri sunulmuştur. Maden ve İşcan (2011) ise Hindistan'daki üniversite öğrencilerinin Türkçe öğrenme amaçları ve yaşadıkları sorunları belirlemiş ve bu konudaki eksiklikler üzerinde durmuşlardır. Tüm bu çalışmalar göstermektedir ki yabancılara Türkçe öğretirken karşılaşılan sorunlar her aşamada bulunmaktadır ve bu durumdan en çok etkilenenler yine eğitim almak üzere ülkemizde bulunan öğrencilerdir. Yapacağımız çalışma ile öğrencilerin Türkçeye yönelik görüşlerinin belirlenmesi ve ortaya çıkan sorunların çözülmesi bu bağlamda alan yazına katkı sağlayacaktır.

Bu çalışmanın amacı lisans ve lisansüstü eğitim amacıyla Sakarya Üniversitesi'ne gelen öğrencilerin Türkçeye ilişkin görüşlerini belirlemektir. Bu amaçla şu sorulara cevap aranacaktır:

1. Yabancı öğrencilerin Türkçe öğrenme ve Türkçe konuşma ilgili düşünceleri ne yöndedir?

2. Türkçe öğrenirken en çok hangi konuda sıkıntı yaşamaktadırlar?

3. Türkçe öğrenirken uyguladıkları bir yöntem ya da tercih ettikleri bir yol var midır?

Lisans ve lisansüstü eğitim için yurt dışından gelen öğrencilerin Türkçe hakkındaki görüşlerinin belirlenmesi hem öğrencilerin Türkiye'de eğitim alırken Türkçe bağlamında yaşadıkları zorlukları belirlemede yardımcı olacaktır hem de Türkiye'de yabancı uyruklu öğrencilere eğitim veren kurumların yararlanmasını sağlayacaktır. Ayrıca bu konu ile ilgilenen diğer araştırmacılara da yol göstermesi açısından önem taşımaktadır.

\section{YÖNTEM}

Bu çalışma, nitel araştırma desenlerinden olgubilim (fenomenoloji) çalışmasıdır. Olgubilim (fenomenoloji/phenomenology) deseni farkında 
olduğumuz ancak derinlemesine ve ayrıntılı bir anlayışa sahip olmadığımız olgulara odaklanmaktadır. Olgular, yaşadığımız dünyada olaylar, deneyimler, algılar, yönelimler, kavramlar ve durumlar gibi çeşitli biçimlerde karşımıza çıkabilmektedir. Bize tümüyle yabancı olmayan aynı zamanda da tam anlamını kavrayamad1ğımız olguları araştırmayı amaçlayan çalışmalar için olgubilim (fenomenoloji) uygun bir araştırma zemini oluşturur. (Yıldırım ve Şimşek, 2011,s:72)

Verilerin toplanmasında görüşme yöntemi kullanılmıştır. Görüşme ("interview”, mülakat), sözlü iletişim yoluyla veri toplama (soruşturma) tekniğidir. (Karasar, 2007,s:165) Veriler, araştırmacılar tarafından geliştirilmiş ve yedi sorudan oluşan yarı yapılandırılmış görüşme formu ile toplanmıştır. Görüşme formunda yer alan sorular geçerlilik ölçütünün sağlanması amacıyla yabancılara Türkçe öğretimi alanının uzmanlarına ve ölçme değerlendirme alanı uzmanına inceletilmiş ve gerekli düzeltmeler yapıldıktan sonra son hali verilmiştir.

Veriler toplanırken yurt dışından Sakarya'ya eğitim için gelen 13 lisans ve lisansüstü öğrencisiyle ayrı ayrı görüşülmüş ve görüşme gönüllülük esasına dayalı olarak yapılmıştır. Görüşme öncesi, görüşmelerin kayıt altına alınacağı, katılımcıların isimlerinin ve özel bilgilerinin hiç bir yerde kullanılmayacağına dair bilgilendirme yapılmış ve öğrencilerin izinleri dâhilinde ses kayıt cihazı ile kayıt altına alınmıştır. Kayıtlarda katılımcıların isimleri kullanılmamış ve katılımclar K1, K2, K3... olmak üzere kodlanmıştır. Görüşmeye lisans ve lisansüstü eğitim alan 13 öğrenci katılmıştır. Öğrencilerin eğitim durumları ve geldikleri ülkelerin bilgisi aşağıdaki tabloda verilmiştir:

Tablo 1. Görüşme yapılan öğrencilerin eğitim durumları ve geldikleri ülkeler

\begin{tabular}{|c|c|c|}
\hline Katılımcı & Eğitim Durumu & Geldiği Ülke \\
\hline K1 & Yüksek Lisans & Irak \\
\hline $\mathrm{K} 2$ & Yüksek Lisans & Azerbaycan \\
\hline K3 & Lisans & Etiyopya \\
\hline K4 & Lisans & Mozambik \\
\hline K5 & Yüksek Lisans & Tanzanya \\
\hline K6 & Yüksek Lisans & Tanzanya \\
\hline K7 & Lisans & Kosova \\
\hline K8 & Lisans & Kazakistan \\
\hline K9 & Lisans & Suriye \\
\hline K10 & Yüksek Lisans & Gürcistan \\
\hline K11 & Yüksek Lisans & Ürdün \\
\hline K12 & Lisans & Kazakistan \\
\hline K13 & Doktora & Makedonya \\
\hline
\end{tabular}


Veriler çözümlenirken nitel veri analiz tekniklerinden içerik analizi kullanılmıştır. İçerik analizinde temel amaç, toplanan verileri açıklayabilecek kavramlara ve ilişkilere ulaşmaktır. İçerik analizinde temelde yapılan işlem, birbirine benzeyen verileri belirli kavramlar ve temalar çerçevesinde bir araya getirmek ve bunları okuyucunun anlayabileceği bir biçimde düzenleyerek yorumlamaktır (Yıldırım ve Şimşek, 2011, s:227). Görüşmeler sonucunda elde edilen veriler öncelikle yazılı ortama aktarılmış ve hiçbir cümlenin üzerinde noktalama ve yazım düzeltmesi yapılmamıştır. Toplanan verilerin kodlaması yapılmış, her soru için ayrı ayrı tablolar hazırlanmış ve katılımcıların ifadelerinde yer alan aynı ya da benzer temalar ortak bir paydada toplanmıştır. Verilen cevapların frekansları tablolarda verilmiştir.

\section{BULGULAR VE YORUM}

Sakarya Üniversitesinde lisans ve lisansüstü eğitimi alan yabancı uyruklu öğrencilerin Türkçeye ilişkin görüşlerini belirlemek amacıyla yedi sorudan oluşan yarı yapılandırılmış görüşme formu hazırlanmıştır. Sorulan sorular ile öğrencilerin Türkçeye yönelik algıları ve Türkçe öğrenirken yaşadıkları zorluklar belirlenmeye çalışılmıştır. Öğrencilerin Türkçeye dair görüşlerinin sorulduğu sorulara verdikleri cevaplar aşağıdaki tablolarda belli alt başlıklar altında toplanmıştır.

Tablo 2. "Türkçeyi öğrenmeye nerede başladınız?" sorusuna verilen cevaplar

\begin{tabular}{ll}
\hline Türkçe Öğrendikleri Yerlere Göre & $\mathrm{f}$ \\
\hline Kendi Ülkesinde Türkçe Öğrenenler & 9 \\
Türkiye'de Türkçe Öğrenenler & 4 \\
\hline
\end{tabular}

Tablo 2'de yabancı öğrencilerin "Türkçe öğrenmeye nerede başladınız?" sorusuna verdikleri cevapların dağılımı yer almaktadır. Katılımcıların 9'u geldikleri ülkede Türkçeyi öğrenmişlerdir. Verilen cevaplar arasında, ülkesinde bulunan ve Türk Okulu olarak bilinen ilk ve orta öğretim kurumlarında Türkçeyi öğrenme, üniversite eğitimini ülkelerinde bulunan Türk Dili ve Edebiyatı bölümlerinde alma bulunmaktadır. Katılımcıların 4 tanesi Türkiye'de Türkçe öğrendiklerini belirtmiştir. Bu katılımc1ların neredeyse tamamını Türkiye'deki bir Türkçe Uygulama ve Araştırma Merkezi'nde Türkçe öğrenen adaylar oluşturmaktadır. “Türkçe öğrenmeye nerede başladınız?” soru- suna verilen cevaplara göre yabancı ögrrencilerin daha çok geldikleri ülkede Türkçe öğrenmeye başladıkları ya da Türkçe ile karşılaştıkları sonucu çıkmaktadır. Katılımcıların bu soruya verdiğin cevapların bazıları şu şekildedir:

K5: "Ben Türkiye'ye geldim o zaman başladı. Sakarya kampüste bir merkez bir uygulama merkezi var orada TÖMER orada başladım."

K8: “...Türk kolejine gittim orada Türkçe biraz okuduk sonra okulumuzdan iyi okuyan üç öğrenciyi Türkiye'ye yani praktik olarak yani göndermişti. Ondan yani başladı diyebilirim. Öyle ilgilenmeye başladım Türkçe okumaya öğrenmeye." 
Tablo 3. "Türkçe öğrenirken sizi en çok zorlayan ne oldu? “ sorusuna verilen cevaplar

\begin{tabular}{ll}
\hline Türkçe Öğrenirken En Çok Zorlanılan Noktalar & $\mathrm{f}$ \\
\hline Dil Bilgisi ve Terimler & 6 \\
Telaffuz & 4 \\
Her Noktada Zorluk Çekilmiştir & 1 \\
Hiçbir Noktada Zorluk Çekilmemiştir & 2 \\
\hline
\end{tabular}

Tablo 3, katılımcılara sorulan “Türkçe öğrenirken sizi en çok zorlayan ne oldu?" sorusuna verilen cevapların dağılımını göstermektedir. Katılımcıların 6 tanesi bu soruya dil bilgisi ve dil bilgisi terimleri cevabını vermiştir. $\mathrm{Bu}$ konudaki katılımcı ifadeleri şu şekildedir:

K3: "Şimdi benim bi tek yani dil bilgisi zor oluyor. Ekler var onları şey yapmak... Birleştirmek biraz zor oluyor."

K8: " Gramer. Gramerle bizim hiç benzemiyor. Çünkü ilk hep -yor ekiyle konuşuyordum eee gelecek zamanda da geçmiş zamanda da hep -yor'la konuşuyordum. Tüm zamanlarm bir yerde topluyordum."

Telaffuz ise yabancı öğrencilerin zorlandığı bir diğer konu olarak ön plana çıkmaktadır. Katılımcıların 4'ü Türkçede en çok zorlandıkları konunun telaffuz olduğunu dile getirmişlerdir. Özellikle birçok dilde olmayan i,ö,ü gibi seslerin telaffuzu öğrencilerin zorlanmasına neden olmaktadır. Telaffuzda zorlandığını belirten katılımcıların cevapları şu şekildedir:

K10: "Telaffuz. Hala çok zorlanıyorum. Bizde, sizde $i, l$ var bizde yok mesela çok zorlanıyorum şimdi de ayni."

K11: “Telaffuz şimdiye kadar. Ü'ler yok, ö'ler falan o noktalı olanlar var ya noktalı olup olmadığııı fark edemiyorum."

Katılımcıların 2'si Türkçe öğrenirken hiç zorluk çekmediğini belirtirken bir tanesi ise Türkçe öğrenirken her noktada zorlandığını ifade etmiştir. Bu tabloya göre yabancı öğrenciler Türkçeyi öğrenirken en çok dil bilgisi konularında zorluk çekmektedirler.

Tablo 4. “Türkçe öğrenirken sizi en çok zorlayan dil bilgisi konusu ne oldu?" sorusuna verilen cevaplar

\begin{tabular}{lc}
\hline Türkçe Öğrenirken En Çok Zorlanılan Dil Bilgisi Konuları & $\mathrm{f}$ \\
\hline Ekler & 6 \\
Cümle yapısı & 2 \\
Dolaylı Anlatım & 1 \\
Zorlandığı konu yok & 4 \\
\hline
\end{tabular}

Katılımcılara yöneltilen “Türkçe öğrenirken sizi en çok zorlayan dil bilgisi konusu ne oldu?" sorusuna, katılımcıların verdiği cevaplar Tablo 4'te yer almaktadır. Buna göre yabancı öğrencilerin sekiz tanesi Türkçe öğrenirken en çok zorlandıkları dil bilgisi konusunun ekler olduğunu belirtmiştir. Ekler konusu içinde ise fiillere gelen ekler ve çatı ekleri en çok zor- lanılan ek türleri olmuştur. En zorlandığı dil bilgisi konusunun ekler olduğunu söyleyen katılımcıların cevaplarından bir kaç örnek şu şekildedir:

K1: "Eee.. bir konu vardı. Hangisiydi...fiilden fiil yapım ekleri, isimden fiil yapım ekleri orada çok zorlandım. Bir tek o konuda çok zorlandım." 
K11: "Dil bilgisi en sevdiğim şey aslında çok zorlanmadım. Ama ekler zor. Ekler çok zor çünkü $\imath$, a bunlar mesela seomek $i$ alır 1 alır, belirtme, yönelme... Yönelme çok kolay diyelim ama belirtme çok kötü. Belirtme ne zaman belirtme kullanacağımızı kullanmayacağımızı onu şimdiye kadar uğraşıyoruz yani. Sana sordum seni mi sordum? Bunu kullandim buna mı kullandım? Hayır sormak a. Sana soruyorum. Şimdi onlar senden istedim. Bunlar biraz..."

Söz dizimi ise yabanc1 öğrencilerin zorlandıkları bir diğer dil bilgisi konusudur.
Türkçedeki kurallı cümlelerin öge dizilişinin “Özne+Nesne+Yüklem” olması, katılımcıların 2'sinin bu dizilişi gerçekleştirirken zorlanmasına sebep olmuştur. Katılımcıların biri, Türkçe öğrenirken anlatım biçimlerinden olan dolaylı anlatımda zorlandığını sorulan soruya cevap olarak vermiştir. İki katılımcı ise zorlandığı bir dil bilgisi konusu olmadığını dile getirmiştir. Yukarıda yer alan tabloya bakıldığında Türkçe öğrenen yabancı öğrencilerin en çok zorlandıkları dil bilgisi konusunun ekler olduğunu ortaya çıkarmaktadır.

Tablo 5. "Türkçe konuşurken hatırlayamadığınız kelimeler için ne yapıyorsunuz?" sorusuna verilen cevaplar

\begin{tabular}{ll}
\hline Türkçe Konuşurken Hatırlanmayan Kelimeler için Yapılanlar & $\mathrm{f}$ \\
\hline Kaynak Kullanımı & 2 \\
Dil Yardımı ile Anlatma & 5 \\
Dil Dışı Yöntemlerle Anlatma & 6 \\
\hline
\end{tabular}

Yukarıda yer alan tablo te yabancı öğrencilerin "Türkçe konuşurken hatırlayamadığınız kelimeler için ne yapıyorsunuz?" sorusuna verdikleri cevaplar yer almaktadır. Bu tabloya göre öğrencilerin 6 tanesi hatırlayamadığı kelimeler için dil dışı yöntemleri kullanmaktadır. Dil dişı yöntemlerin içerisinde jest ve mimikler ile anlatma, işaret ederek gösterme ve çizerek anlatma yer almaktadır. Katılımcıların büyük çoğunluğu hatırlayamadığı bir kelime somut bir nesne ise gösterme eğilimine girmektedir. Eylemleri ise jest ve mimikleriyle anlatmaktadır. Katılımciların 5'i hatırlayamadığı bir kelime olduğunda dil aracılığı ile anlatmaya çalışmaktadır. Katılımcılardan, kelimeleri dil aracllığıyla anlatmaya çalışanlar, çoğunlukla anlatma istedikleri kelimelerin eş anlamlılarını kullanmakta yahut farklı cümlelerle anlatmak istediklerini ifade etmektedirler. Bu konudaki ifadelerin bazıları aşağıda yer almaktadır:
K2: “Düşünüyorum. Başka kelimeler düşünüyorum acaba ne söyleyebilirim diye..."

K13: "Şimdi Türkçe çok zengin bir dil. Farklı ya da ona benzer bir kelime kullanıyorum. Evet çünkü mesela bir kelimenin kaç tane yani bir şeyde kaç tane kelime kullanabilirsin. Ilkini hatırlamıyorsam ona benzer kelime kullaniyorum."

Türkçe ile ortak kelimelerin bulunduğu bazı dilleri konuşan katılımcilar ise bu ortak kelimeler yardımı ile anlaşmaya çalışmaktadır. Uluslararası kullanımı yaygın bir dil olan İngilizce ile hatılayamadığı kelimeleri anlatmaya çalışan katılımcılar olsa da bu sayı fazla değildir. $\mathrm{Bu}$ tabloya göre yabancı öğrenciler hatırlayamadığı kelimeleri ifade etmek için çoğunlukla jest- mimik ve beden dillerini kullanmaktadır. Katılımcıların 2'si ise kelimeleri hatırlayamadıkları zaman sözlük ya da internet kaynakları ile anlaşmaya çalışmaktadır. 
Tablo 6. “Türkçe konuşurken kaygılandı̆̆ınız oluyor mu?” sorusuna verilen cevaplar

\begin{tabular}{lc}
\hline Türkçe Konuşurken Oluşan Kaygı Durumu & $\mathrm{f}$ \\
\hline Kaygı Yok & 10 \\
Kaygı Var & 2 \\
Zaman Zaman Kaygı Var & 1 \\
\hline
\end{tabular}

Tablo 6'da yabancı öğrencilere yöneltilen “Türkçe konuşurken kaygılandığınız oluyor mu?" sorusuna verilen cevaplar yer almaktadır. Tabloya göre yabancı katılımcların 10 tanesi Türkçe konuşurken kaygı duymadığını ifade etmiştir.

K6: "Ben kesinlikle hiç yani diğerleriyle konuşurken hiç korkmuyorum hiç utanmıyorum yani konuşurken yani yanlış ya da doğru konuşuyorum. Yani zaten öğrenmek istiyorum yani istiyorsan..."

K11: "I th. Korkum yok. Çünkü İngilizce öğretmendim. Dil yabancı dil öğretirken hiç korkmaman gerektiğini ne kadar önemli olduğunu bildiğim için hiç korkmuyorum. Denemeniz lazım bence."

Tablo 7. “Türkçe öğrenirken okuldaki dersler ve kurslar dışında kendi yaptığınız bir şey var mı?” sorusuna verilen cevaplar

\begin{tabular}{ll}
\hline Türkçe Öğrenirken Okuldaki Dersler ve Kurslar Dışında Yapılanlar & $\mathrm{f}$ \\
\hline Medyayı ve Kitle İletişim Araçlarını Kullanmak & 7 \\
Basılı Kaynaklardan Yararlanmak & 3 \\
Okul Dışı Ders ve Kurslara Katılmak & 1 \\
Sohbet Etmek & 2 \\
\hline
\end{tabular}

Katılımcılara yöneltilen "Türkçe öğrenirken okuldaki dersler ve kurslar dışında kendi yaptı̆̆ınız bir şey var mı?" sorusuna verilen cevaplar Tablo 7'de yer almaktadır. Yabancı öğrencilerin 7 tanesi medyayı ve kitle iletişim araçlarını kullanarak Türkçeyi ilerlettiklerini ifade etmişlerdir. Medya ve kitle iletişim araçlarından en çok dikkat çekenler Türk dizileridir. Katılımcıların bir kısmı, kendi ülkelerinde yayınlanan Türk dizileri sayesinde zaten Türkçeye aşina olduklarını, Türkiye'ye geldiklerinde de dizi izleyerek Türkçelerinin gelişimlerine
Katılımcların 2'si ise Türkçe öğrendikleri ilk andan itibaren kaygılarının var olduğunu ve bu durumun her zaman geçerli olduğunu belirtmişlerdir:

K4: "Evet. O yüzden yani sinıfta mesela çok çekiniyorum konuşmaktan. Belki ben düşünüyorum ben yanlış konuşuyorum ama aslında doğru konuşuyorum..."

Katılımclardan bir tanesi ise zaman zaman kaygının yer aldığını, bu kaygı durumunun, bulunduğu ortamın resmiliğine ya da doğallığına göre değiştiğini belirtmiştir. 
öğrenmeye yardımcı olacak kaynak kitapları ve Türk hikâye ve romanlarını okuyarak Türkçelerini geliştirdiklerini ifade etmişlerdir. Aynı zamanda Türkçe eserleri kendi dillerine tercüme ederek bu konuda fayda sağladığını belirten öğrenciler de bulunmaktadır. Katılımcıların iki tanesi ise Türklerle yahut farklı ülkelerden gelen öğrencilerle sohbet ederek Türkçelerini ilerlettiğini cevap olarak vermiştir. Okul dışında ders ve kurslara katıldığını ifade eden ise katılımcılar arasında bir kişidir. Bu kurslar gitar, piyano gibi kişisel gelişim kurslarının yanı sıra okudukları bölümle ilişkisi olabilecek akademik kurslar da olabilmektedir. Kurslara katıldığını belirten katılımcının cevabı şu şekildedir:

K8: "Buradan yurt diş eee her zaman boştum önceden. Burada kurslar buldum. Gitar kursu, Arapça kursu, piyano kursu..."

Tablo 8. "Sizce yabancı bir kişi Türkçeyi hangi amaçla öğrenmelidir?" sorusuna verilen cevaplar

\begin{tabular}{lc}
\hline Türkçeyi Öğrenme Amacı & $\mathrm{f}$ \\
\hline Kişisel Sebepler & 5 \\
Siyasi ve Ekonomik Sebepler & 4 \\
Sosyal Sebepler & 2 \\
Eğitim & 2 \\
\hline
\end{tabular}

Tablo 8'de yabancı öğrencilerin "Sizce yabancı bir kişi Türkçeyi hangi amaçla öğrenmelidir?" sorusuna verdikleri cevapların dağılımı bulunmaktadır. Katılımcıların 5'ii kişisel sebeplerden dolayı Türkçenin öğrenilmesi gerektiğini belirtmiştir. Bu kişisel sebeplerin içinde ikinci dil edinme ön plana çıkmaktadır. Öğrencilerin Türkçe öğrenme sebeplerinin başında ikinci dil edinip kişisel gelişimine katkıda bulunmak yer almaktadır. Derdini anlatabilmek, farklı kültürleri öğrenmek, Türkçeyi sevmek, kendini geliştirmek de öğrencilerin kişisel olarak belirttiği sebepler arasında yer almaktadır.

K4: "Illk önce kendini geliştirmek için, iletişim kurmak için...Evet bunlar. Bir de bana ben yabancı dile öğrenmek çok seviyorum. Hatta şu ana kadar dört beş dil öğrendim ya da öğrenmeye çalışıyorum."

Görüşmeye katılan katılımcıların 4 tanesi ise siyasi ve ekonomik sebeplerden dolayı Türkçe öğrenileceğini cevap olarak vermiştir. Siyasi ve ekonomik sebepler içerisinde en dikkat çeken ise yabancı öğrencilerin kendi ülkelerinde iş bulmaya katkı sağlayacağını ifade etmeleridir. Türk iş adamlarının ve Türk girişimcilerin işyerlerinde çalışmak amacıyla Türkçe öğrenebileceklerini ifade etmelerinin yanı sıra Türkçe bilmenin ülkelerinde fayda sağlayacağını düşünenler de bulunmaktadır. Aynı zamanda Türkiye'de iş bulma konusunda da fayda sağlayacağını ve bu amaçla Türkçe öğrenmenin gerekli olduğunu belirtmişlerdir. Türkiye'nin çeşitli burs imkânlarına sahip olması, Türkiye'nin gelişen bir ülke olması ve bu durumun da Türkçe öğrenmek için bir amaç olduğu da verilen cevaplar arasında bulunmaktadır.

K7: "İş imkânı var ilk önce. İkincisi de yani böyle bir burs sistemi başka ülkede yok yani cidden çok araştırdim ve dolayısiyla böyle bir imkân cidden paha biçilemez ve bence hani hem eğitim için hem iş imkânı için çok gerekli bir şey."

Türkçe öğrenme amacına cevap olarak sosyal sebepleri belirtenlerin sayısı ikidir. Sosyal sebeplerin arasında iletişim kurabilmek ve Türk insanıyla rahatça anlaşabilmek yer almaktadır. Aynı soruya eğitim cevabını verenler ise yine ikikatılımcıdır. Türkiye'de eğitim sektöründe çalışmak ya da geldikleri ülkede Türkçe eğitim vermek amacıyla Türkçe öğrenildiğini belirten- 
ler bu grupta yer almaktadır. Verilen cevaplara göre yabancı öğrencilerin Türkçe öğrenme amaçlarının genel olarak iş imkânı ve ikinci dil edinimi olduğunu söylemek yanlış olmayacaktır.

\section{SONUÇ VE ÖNERILLER}

Son yıllarda Türkiye'nin yaşadığı hızlı gelişme ve değişim, eğitim ve dil öğrenme amaciyla yurt dışından Türkiye'ye gelen öğrencilerin sayısının artmasını sağlamıştır. $\mathrm{Bu}$ durum yabancı öğrencilerin eğitim durumunu gündeme getirmiştir. Özellikle öğrencilerin dil eğitimi alırken ya da Türkçeyi öğrenirken yaşadığı zorlukların belirlenmesi eğitimin kaliteli bir şekilde ilerleyebilmesi açısından önem arz etmektedir.

$\mathrm{Bu}$ çalışmanın tamamlanmasıyla ortaya çıan sonuçlar yabancı öğrencilerin Türkçeye ilişkin görüşlerini ve Türkçe öğrenirken yaşadıkları sorunlar ile kendilerinin Türkçe öğrenme çabasını ortaya koyması bakımından bilgi verici niteliktedir. Çalışmaya göre öğrencilerin Türkçe öğrenmeye genellikle kendi ülkelerindeki eğitim kurumlarında başladıkları ve bunun devamı olarak Türkiye'ye gelmeyi tercih ettikleri sonucu ortaya çıkmaktadır. Bir diğer önemli nokta ise yabancıların Türkçeyi öğrenirken en çok dil bilgisi konusunda zorluk yaşadıklarıdır. Özellikle dilimizin sondan eklemeli bir yapıya sahip olması dolayısıyla, ekler konusu yabancı öğrencilerin bu konuda sıkıntı yaşamasına neden olmaktadır. Günlük dilde iletişim halinde iken eklerle ilgili bu sorun çok fazla dikkat çekmezken, akademik dile veya yazı diline geçildiğinde öğrencileri kaygılandırmakta ve zorlanmalarına neden olmaktadır. Yabancı öğrencilere dil bilgisi yapıları ve kuralları öğretilirken basitleştirilmesi ve yabancı dil olarak öğretildiğinin unutulmaması yerinde olacaktır (Yıldız ve Tunçel, 2012).
Öğrenciler dili kullanırken dilin her türlü imkânından yararlanmakta ve iletişim kurarken anlatamadıkları sözcükleri ya da ifadeleri farklı bir kelime kullanarak ya da dilin el verdiği ölçüde farklı yollardan anlatarak iletişimlerine devam etmektedirler. Ayrica bu durum yabancı öğrencilerin dilde kaygılarının olmamasıyla da yakından ilgilidir. İletişim kurarken olumsuz bir durumla karşılaşma durumu en asgari düzeyde olduğundan kaygi durumu da doğru orantılı olarak azalmaktadır.

Katılımcıların Türkçe öğrenmek için okul d1şında yaptıkları etkinlikler ya da aktivitelere bakıldığında Türk dizilerinin ve Türk müziklerinin ön planda olduğu göze çarpmaktadır. Maden ve İşcan (2011)'ın yapmış oldukları çalışmalarda da benzer sonuçlar ortaya çıkmış, yabancı öğrencilerin konuşma pratiği yaparak ya da Türk filmlerini izleyerek ve Türk müziklerini dinleyerek Türkçe öğrenmeye katkıda bulunduklarını belirtmişlerdir. Öğrencilerin günlük konuşma dilini öğrendiği diziler bir yönden fayda sağlasa da bazı durumlarda argo sözcüklerin çokluğu ve yanlış dil bilgisi yapılarının bulunması gibi durumlarla karşılaşılması, dizilerin seçiminde öğrencilere yol gösterilmesi gerekliliğini ortaya koymaktadır. Bu konuda yapılacak bir çalışma ile öğrencilerin hem s1kılmayacağ 1 hem de olumsuz yönde etkilenmeyeceği medya araçlarının kullanımı sağlanabilir.

Araştırmanın bir diğer sonucu yabancı öğrencilerin Türkçeyi daha çok iş imkânı için öğrendiğidir. Son yıllarda Türkiye'nin geldiği nokta yabancıların iş bulabilmek için Türkiye'ye gelmesini ve dolayısıyla Türkçe öğrenmelerini sağlamıştır. Bunun yanı sıra öğrencilerin geldikleri ülkede de Türkçenin sağladığı fayda ile iş firsatı elde etmeleri de Türkçenin önemli bir dil olduğu gerçeğini ve önümüzdeki yıllarda daha çok öğrencinin ülkemize bu sebeple geleceğini göstermesi bakımından önemlidir. $\mathrm{Bu}$ 
yüzden Türkçe öğretiminin daha iyi planlanması ve gerek öğretim elemanı gerekse de eğitim programları ve materyaller bakımından da eksiklerinin giderilmesi gerekmektedir.

\section{Kaynakça}

Açık, F. (2008). Türkiye'de Yabancılara Türkçe Öğretilirken Karşılaşılan Sorunlar ve Çözüm Önerileri, Doğu Akdeniz Üniversitesi Eğitim Fakültesi Türkçe Eğitimi Bölümü “Uluslararası Türkçe Eğitimi ve Öğrretimi Sempozyumu'nda sunulan bildiri.

Alyılmaz, C. (2010). Türkçe Öğretiminin Sorunları. Turkish Studies, 5(3), 728-749.

Biçer, N. ; Çoban, İ. ve Bakır, S. (2014). Türkçe Öğrenen Yabancı Öğrencilerin Karşılaştığı Sorunlar: Atatürk Üniversitesi Örneği, Uluslararası Sosyal Araştırmalar Dergisi, 7(29), 125-135.

Candaş Karababa, Z. C. (2009). Yabancı Dil Olarak Türkçenin Öğretimi ve Karşılaşılan Sorunlar. Ankara Üniversitesi Ĕ̆itim Bilimleri Fakültesi Dergisi, 42(2), 265-277.

Doğan, Â. (1989). Yabancıların Türkçe'yi Öğrenirken Karşılaştıkları Güçlükler ve Yaptıkları Bazı Hatalar, Hacettepe Üniversitesi Edebiyat Fakültesi Dergisi, 6(1-2), 259-261.

Durmuş, M. (2013). Türkçenin Yabancılara Öğretimi: Sorunlar, Çözüm Önerileri ve Yabancılara Türkçe Öğretiminin Geleceğiyle İlgili Görüşler, Adıyaman Üniversitesi Sosyal Bilimler Enstitüsü Dergisi Türkçenin Ĕ̆ğtimi Öğretimi Özel Sayısı, 11, 207-228.

Göçer, A. ve Moğul S. (2011). Türkçenin Yabancı Dil Olarak Öğretimi ile İlgili Çalışmalara Genel Bir Bakış, Turkish Studies: International Periodical For The Languages, Literature and History of Turkish or Turkic, 6(3), 797-810.

Güleç, İ. ve İnce, B. (2013). Türkçe Öğrenen Yabancıların Günlük Yaşama İlişkin Kültürel Algıları Üzerine Bir Araştırma, Sakarya Üniversitesi Ĕ̆itim Bilimleri Enstitüsü Dergisi, 3(3), 95-106.

Karasar, N. (2007). Bilimsel Araştırma Yöntemi, Nobel Yayın Dağııım: Ankara.

Maden, S., İşcan, A. (2011). Yabancı Dil Olarak Türkçe Öğretimi Amaç ve Sorunlar (Hindistan Örneği), Karadeniz Sosyal Bilimler Dergisi, 3(5), 23-37.

WEB1， http://osym.gov.tr/dosya/1-58220/h/21yabanciogrenciuyruk.pdf adresinden 20.03 .2015 tarihinde erişilmiştir.

WEB2, http://www.osym.gov.tr/dosya/1-60408/h/21yabanciogrenciuyruk.pdf adresinden 20.03 .2015 tarihinde erişilmiştir.

WEB3, http://www.osym.gov.tr/dosya/1-69412/h/21yabanciogrenciuyruk.pdf adresinden 20.03.2015 tarihinde erişilmiştir.

Yağmur, K. (2013). Dil Öğretiminde Ana Dili, İkinci Dil ve Yabancı Dil Kavramları. Yabancılara Türkçe Öğretimi El Kitabı. Durmuş M. ve Okur A. (Editörler). Ankara: Grafiker Yayınları.

Yıldırım, A. ve Şimşek, H. (2011). Sosyal Bilimlerde Nitel Araştırma Yöntemleri, Ankara: Seçkin Yayınevi.

Yıldız, Ü. ve Tunçel, H. (2012). Yabancı Dil Olarak Türkçe Öğretiminde Karşllaşılan Sorunlar ve Öneriler. Yabancı Dil Olarak Türkçe Öğretimi (YDTÖ). Kılınç A. Ve Şahin A. (Editörler). (İkinci Baskı), s. 115145. Ankara: Pegem Akademi. 


\section{Extented Summary}

In recent years, reaching to the information has become easy thanks to development of technology, thus people has started to communicate internationally. Interaction between people has increased as a result of this fast change in the world and the interaction between people. Not only Turkey's development in social and economic fields but also significance of Turkey's development international relations and education, and attractiveness of scholarship opportunities in Turkey has led foreigners' interest about Turkey to increase.

Rise of teaching Turkish activities and the number of the foreign students coming to our country has brought along the problems foreign students have and their needs. Foreign students who started to live in Turkey both have been trying to keep up with social and cultural life and in order to compromise with Turkish people they have started to communicate. This situation causes students to encounter difficulties and various problems from time to time.

The purpose of this study is to determine the thoughts of the students who come to Turkey to get graduate and postgraduate education. Answers to the questions below will be sought with this purpose:

a) What are the foreign students' thoughts about learning Turkish and speaking Turkish?

b) In what subject do they encounter difficulties at most?

c) Are there any technique or any method while learning Turkish?

Determining the students', who come from abroad to get undergraduate and graduate education, thoughts both help determining the difficulties which are encountered by the foreign students while they are getting Turkish education and the institutions which are giving education to the foreign students in Turkey will benefit from it. Moreover, it is important in terms of leading researchers who are interested in this subject.

This study is the study of phenomenology from the patterns of qualitative research. Phenomenology pattern focuses on phenomenon we know but do not have detailed view. Phenomenon can be encountered in various ways such as events, experiences, perceptions, tendencies, terms and situations. Phenomenology supplies proper research ground for the studies which aim to research the phenomenon which we are not unfamiliar with but cannot figure out completely. (Yıldırım and Şimşek, 2011)

Interview method was used to gather information. Interview is the method of gathering information through verbal communication. (Karasar, 2007) Data were gathered with the semi-structured interview form which was prepared by researchers. In order to supply validity criterion, questions on the form were analyzed by the experts of teaching Turkish field and the experts of assessment and evaluation field and then the questions were finalized.

13 graduate and postgraduate students who came to Turkey for education were interviewed separately while gathering information and interviews were done based on voluntariness. Before interview, attendants were informed that the interview would be recorded but their names and private information would not be used in anywhere and interviews were recorded by the voice recording devices with attendants' permission. Attendants' names were not used in the records and they were coded as K1, K2, $\mathrm{K} 3$ in the records. Content analysis method from qualitative data analyses methods was used to analyze data. 
Primary purpose of content analysis is to reach the terms and relations with which gathered information can be explained. Main process in the content analysis to put similar terms and themes together and to organize them in the way readers can understand. (Yıldırım and Şimşek, 2011). Inıtially, gathered data as the result of the interviews were put down on paper and punctuation correction was not done on the sentences. Gathered data were coded, diagram for each questions were prepared and similar statements of the attendants were grouped together. Frequency of the given answers were shown by percentage.

Emerging results with the completion of this study have informative aspect as they reveal foreign students' thoughts about Turkish and problems that they encounter as they make effort to learn Turkish. According to the study, it is concluded that students, generally, start learning Turkish in the institutions in their country and then they prefer to come to Turkey as a continuation of it. Another important point is their having difficulty in grammar subjects while learning Turkish. As a result of our language's being agglutinative language, subject of suffixes caused foreign students to have difficulty. As it does not draw much attention in communication with daily language, it becomes harder when it comes to the academic and writing.

Students use every opportunity as they use language and continue communications by using different words instead of the words they cannot narrate or by benefiting from other ways that language supplies. Moreover, this situations is closely related with foreign students' not having anxiety in language. As the possibility of encountering with negative situations is minimized as communicating, state of anxiety decreases directly proportionally.

When we focus on the activities which attendants join in order to learn Turkish out of school, it is seen that Turkish series and Turkish music are featured ones. The series by which students learn daily language supplies benefit in a way, but their containing of crowd of slang words and wrong grammar structures make it necessary to lead students as they choose series. Both entertaining and positively affecting materials can be provided with the help of a study which can be done in about this subject.

Another result of the study is that foreign student learn Turkish for more job opportunities. The point where Turkey has come lately has led foreign students to come Turkey and learn Turkish. Besides, Turkish supplies more job opportunities even in the countries where students come from. This situations is important as it shows that Turkish is an important language and more students will come to our country because of this reason. Therefore, it is necessary to have a well-planned Turkish education and sufficient instructor, training programs and materials. 